\title{
Effect of work-life balance on performance of money deposit banks in south-south Nigeria
}

\author{
Bogofanyo Salolomo ${ }^{a^{*}}$ and Emmanuel Kalu Agbaeze ${ }^{a}$
}

${ }^{a}$ Department of Management, Faculty of Business Administration, University of Nigeria, Enugu Campus, Nigeria

\section{H R O N I C L E}

Article history:

Received: November 23, 2018

Received in revised format: No-

vember 24, 2018

Accepted: January 15, 2019

Available online:

January 15, 2019

Keywords:

Work life balance

Performance

Managerial support

Alternative work arrangement

\section{A B S T R A C T}

Researching on the concept of work life balance (WLB) becomes imperative for any organization in order to enhance performance efficiency especially the sector concerned. This empirical research is focused on investigating the effect of work-life balance on the performance of money deposit banks in south-south region of Nigeria. In reviewing literature, the study explores alternative work arrangement and managerial support as dimensions of work like balance (the predicting variable), and performance as a criterion variable used for goal attainment as measure. 2562 staff of 12 banks spanning through six states was used as population size. Cochran sample size determination statistical technique was used to determine 485 sample size for the study. Questionnaire was used to collate data and was analyzed with Simple Linear Regression and Pearson product moment correlation with the aid of Statistical Package for Social Science (SPSS 17.0 windows). The result shows that work life balance demonstrated a great significant effect on the performance of money deposit banks as the dimensions alternative work arrangement such as compress work weeks, telecommuting, flexi time, job sharing and managerial supports predict employee goal attainment. Based on the findings, the study recommends that management should judiciously adopt and implement alternative work arrangement in order to offer a family-friendly atmosphere to attract and retain qualified employees to increase productivity.

\section{Introduction}

Work-life balance is one of the concepts in organization behavior that have attracted wide range of interest amongst industrial actors and researchers. Amjad Ali et al. (2014) define work life balance as the proper prioritizing between "work" (career and ambition) on the one hand and "life" (Health, pleasure, leisure and family) on the other hand. Conversely, Obiageli et al. (2015) describe the concept as a very important phenomenon that is of great concern to various employees in both private and public sector. In their opinion, work-life balance goes beyond prioritizing the work role and one's personal life. It also affects the social, psychological, economical and mental well-being of the individual. All these are reflected in the output of the individual, which affect the performance in the work place for the long run. Work-life balance has shown to have implication on employee's attitude, behavior, wellbeing as well as organizational effectiveness (Eby et al., 2005; Obiageli et al., 2015).

\footnotetext{
* Corresponding author.

E-mail address: bsalolomo@gmail.com (B. Salolomo) 
Historically, the concept currently known as work-life balance has undergone nomenclatural changes as it was captured in some literatures as work/family life balance others refer to it as life role balance or role balance. Marks and MacDermid (1996) in light of the latter title define role balance as "the tendency to become fully engaged in the performance of every role in one's total role system, to approach every typical role and role partner with an attitude of attentiveness and care". Its changes in concept have attracted different definitions including that of one explained earlier.

Work life balance refers to the effective management of multiple responsibilities at work, at home, and in the other aspects of life (Naithani, 2010). It is an issue that is important both for the organizations and the employees. In recessing economic scenario, organizations look forward for higher productivity and need employees with improved work-life balance as an employee with better work-life balance will contribute more meaningfully towards the organizational growth and success. The term work-life balance is commonly used as a more comprehensive expression to describe policies that have been previously termed "family-friendly", but are now extended beyond the scope of the family. Sturges and Guest (2004) posit that work and family are the two most important domains in a person's life and their interface has been the object of study for researchers world-wide. Valk and Srinivasan (2011) expressed the need to balance and integrate family needs and career requirements.

However, the dynamic nature of today's business environment and the high level of competitiveness in the banking sector with the concern of who should be the market leader, has driven bank managers to give their staff excessive work load in order to meet target. In a bid to satisfy the employer's demand and for fear of losing their jobs, employees are compelled to stay longer hours which is detrimental to their personal life. These in a way affect the upbringing of children, lead to broken and unhappy homes and poor social life of employees especially in money deposit banks (Obiageli et al., 2015). Money deposit banks in Nigeria are known for long hour work culture and high workloads on its employees in order to meet with reforms of minimum capital base for operations and other demands.

Understandably, Shobitha and Sudarsan (2014) state that any imbalance between organizational and personal commitments and the inefficient management of life priorities can lead to serious consequences in each other or all of the work family life domains. It is against this backdrop that the researcher corroborates effort with other researchers in seeking to unravel the effect of work-life balance on the performance of money deposit bank in South-South zone of Nigeria.

\section{Objective of the study}

The main objective of this study is to examine the effect of work-life balance on the performance of money deposit banks in South-South region, Nigeria. The Specific objectives of the study will seek:

i. To examine the nature of relationship between alternative work arrangements and goal attainment in money deposit banks, South-South, Nigeria,

ii. To establish the extent to which managerial support affect goal attainment in money deposit banks, South-South, Nigeria.

\subsection{Research questions}

To achieve the objectives outlined above, the researchers developed the following research questions to guide the study.

i. What is the nature of relationship between alternative work arrangements and goal attainment in money deposit banks, South-South, Nigeria? 
ii. To what extent does managerial support affect goal attainment in money deposit banks, South-South, Nigeria?

\subsection{Research hypotheses}

Based on the highlighted research objectives and research questions, the following research hypotheses using the Alternate $\left(\mathrm{H}_{\mathrm{a}}\right)$ form are formulated to effectively guide and direct this study.

$\mathbf{H}_{\mathbf{a} 1}$ Alternative work arrangements such as Job sharing, flexi time, compress work weeks and telecommuting have positive relationships with goal attainment in deposit money banks, South-South, Nigeria. $\mathbf{H}_{\mathbf{a} 2}$ Managerial supports affect goal attainment in deposit money banks, South-South, Nigeria.

\subsection{Review of the related literatures}

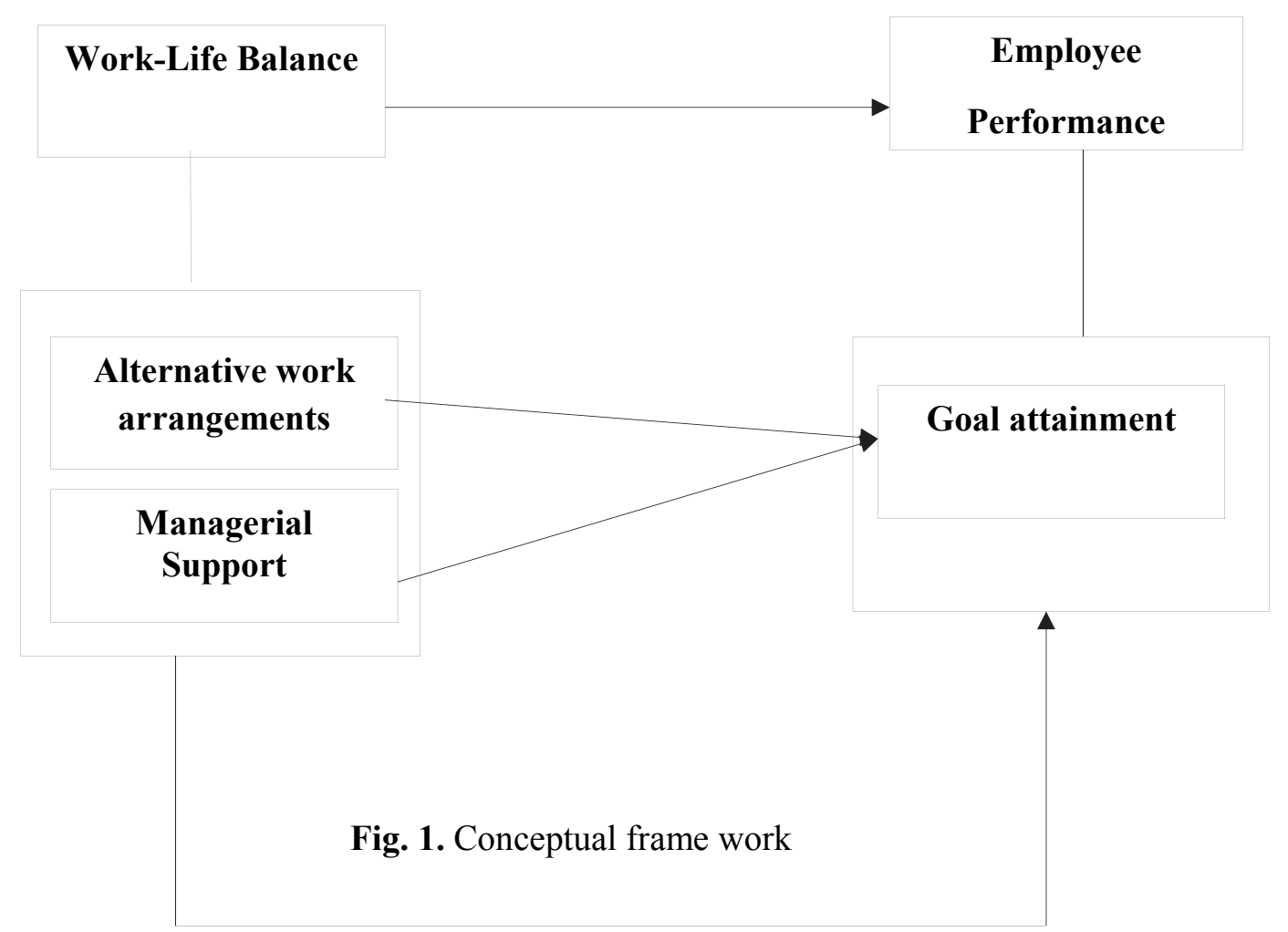

The arrows indicate the direction of the relationships that exist between the independent and dependent variables as well as the dimensions and measures, thus, the review of related concepts below.

\subsection{Concept of Work-life Balance (WLB)}

The term work-life balance was coined in 1986, although its usage in everyday language was sporadic for a number of years. Interestingly, work/life program existed as early as 1930's. Before World War II, the W.K. Kellogg Company created four-six hour shifts to replace the traditional three daily eighthour shifts, and the new shifts resulted in increased employee morale and efficiency (Lockwood, 2003). The concept work-life balance has undergone semantic changes over time, some scholars call it work/family life balance, others refer to it as life role balance and the others role balance. Despite the semantic differences they all express the need to create an obligatory balance in one's various life domains. Work life balance refers to the effective management of multiple responsibilities at work, at home, and in the other aspects of life (Naithani, 2010). According to Amjad Ali et al. (2014), work-life 
balance is the proper prioritizing between "work" (career and ambition) on the one hand and "life" (Health, pleasure, leisure and family) on the other hand. Conversely Obiageli et al. (2015) describe the concept as a very important phenomenon that is of great concern to various employees in both private and public sector. In their opinion work-life balance goes beyond prioritizing the work role and one's personal life. It also affects the social, psychological, economical and mental well-being of the individual. All these are reflected in the output of the individual, which affects his or her performance in the work place on the long run. Work-life balance has shown to have implication on employee attitude, behavior, wellbeing as well as organizational effectiveness (Eby et al., 2005). It is an issue that is important both to the organizations and to employees. In recessing economic scenario, organizations look forward for higher productivity and need employees with improved work-life balance as an employee with better work-life balance will contribute more meaningfully towards the organizational growth and success. Tayfun and Catir (2014) accredit the consequences resulting from the imbalance work-life to technological progress in the work place which causes the changes within work life. In view of these, the concept of work and the qualities of the employees have changed as well which has affected the employee and organization bringing role distributions in life. They further opined that at the present the work place is saturated not only by men, but women also work and earn. The wish of men-women to fulfill their responsibilities thoroughly made it a need to establish the balance. They made attempt to explicitly the work-life balance concept by defining it as the organization's gaining advantage with the employee's aim to evaluate their experiences in the business or in the areas out of the work. Work- life balance comprises four components. The first component is time: how much time is spent at work, compared to how much time is spent engaged in other activities. The second component is related to behavior, such as, work goal accomplishment, as work life balance is based on ones' belief that one is able to accomplish what he/she would like at work and in his/her personal life. Two additional issues or components are Strain and Energy. Strain has been defined as a third source of inter role conflict (Greenhaus \& Beutell, 1985). The rationale for including energy is consistent with the notion of time; energy is a limited resource and relevant to employee being able to accomplish work and/or non-work related goals.

\subsection{Work-life Balance Domains (WLBD)}

Reviewed literature shows multiple domains and is not restricted to the domains of work and family only. Warren (2004) opined that over 170 different life domains have been identified in previous investigations. The major ones include domains of work, financial resources, leisure, dwelling and neighborhood, family, friendships, social participation and health. All these domains of life are closely related to each other, therefore, this study pays attention to the major life domains which includes; worklife domain, family-life domain, social-life domain and personal life domain.

\section{i. Personal Life Domain}

This item consists of the overall health, relationships ambition and spiritual life of employee as is contrast to his/her work life. When employee's job structure or design creates allowance for employee to go in pursuit of these areas it enhances his/her satisfaction and motivates him/her to be committed. This holds to the argument that a satisfied employee will be more committed and perform better than an unsatisfied employee.

\section{ii. Family Life Domain}

This characterizes the overall lifestyle of the employee at home; it includes his/her relationship with spouse, children and relatives. Though, the segmentation theory holds that the family and the work place are two separate entities which activities do not influence each other. This theory is not seen to be realistic in the present work cycle because studies have shown that work interference with family due to imbalance has resulted to conflict in the home and eventually leads to breakage of homes. This 
on the other hand places the employee in a psychological trauma that makes it unproductive even at work (Shobitha \& Sudarsan, 2014). Imbalance between work and family life puts employees on pressure by trying their best to be retained in the organization and makes them put more time at work which may be at detriment of their personal life. All these may affect the upbringing of children, lead to broken and unhappy homes and poor social life (Obiageli et al., 2015).

\section{iii. Social Life Domain}

The social life of an employee is one integral component of the existence of any person that needs prior attention. This aspect of a person's life characterizes the moment of leisure and pleasure he or she enjoys outside of home and work this is the time or period an employee spent on engaging in activities that he/she likes that brings a pleasure. This aspect of a person's life serves as a moderator of the person's family and work-life as it eases the tension of family and work pressure. This is an aspect that less attention is given considering workload from office and family issues that needed to be settled, but in the actual sense this is the medium that the employee's mind will be recreated and energized to face the realities of the work place and the family.

\section{iv. Work Domain}

This domain also known as career domain is the most focused domain where, large number of employees pay much attention to, there by neglecting other domains of life to suffer. The average employee spent at least an average of eight (8) hours daily from Monday- Friday in the work place in pursuit of career advancement, the implication of this is that the employee spent greater hours of his twelve (12) hours component of the day on just one of the domains among the four domains identified in this study.

\subsection{Alternative Work Arrangements}

Alternative work arrangements are program designed by organization to save cost and achieve additional benefits for the organizations. Ideally, alternative work arrangements can decrease facility and employee related costs and improve employee recruitment, retention, and morale (Konrad \& Mangel, 2000). According to Smith et al. (2004) the benefits of alternative work arrangement are: improved morale and reduced stress by giving staff more options to balance work and family demands; increased customer service by expanding department hours; retention of valued staff; increased staff productivity and better planning for staff absences. Typical alternative work arrangements include compressed workweeks, telecommuting, flexi-time, job sharing and part-time work.

\subsection{Managerial Support}

Support from management is one factor that cannot be neglected in implementing work-life balance programs. Allen (2001) defined a supportive manager as the one who is sympathetic to the employee's desires to seek balance between work and other life domains and who engages in efforts to help the employee accommodate his or her work and family responsibilities. Study found that supervisory support was an important source of support in coping with problems associated with work and family conflict (Anderson et al., 2002). Even the success of work life balance practices is dependent on supervisor's attitude, skills and behavior. It is in an attempt to assist employees towards an improved management of their work and non-work tasks that many organizations have employed work-life balance initiatives. According to Glass and Fujimoto (1995) "any benefit, working condition, or personnel policy that has been shown empirically to decrease job-family conflicts among employees.

Previous findings in literature reveal that one of the most important components of the informal support received by the employee is a supportive manager (Clark, 2001; Warren \& Johnson, 1995). Managers are viewed as representatives of the organization saddled with the responsibility for directing and evaluating the performances of their subordinates. Rhoades and Eisenberger (2002) assert that employees 
notion of organizational support is as expressed in the favorable or unfavorable orientation of managers towards them. The effectiveness of work-life initiatives rests majorly on the role of the managers of the organization. The manager can easily encourage or discourage the employees from taking advantage of these programs (Oludayo et al., 2015).

\subsection{Employee Performance}

Performance of employee is one of the most discussed issues in the organizations and by researchers holding to the important contribution employee brings to the workplace. Employee performance translates into good service delivery and interaction which affects every area of the organization. To achieve this organizations need to make polices that will encourage employee performance, according to Hill et al., (2001) an “employee's job performance depends on or is a consequence of some combination of ability, effort, and opportunity. But, the measurements can be done in terms of outcomes or results produced". Performance is the record of the outcomes produced on a specified job function or activity during a specified time period (Benardin \& Rusell, 1998). In-line with the above assertion, performance is a function of sets of outcomes produced during a certain time period. Therefore, employee performance is the assigned tasks targets reached by employees within particular period of time. Performance is not only related to the action but also involves judgment and evaluation process (Ilgen \& Schneider, 1991). Campbell (1993) posits that performance is related to what the individual employee does in fulfilling his / her duties and the activities that can be examined and measurable. Frese et al. (2002) was emphatic in his assertion that organization needs high performing employees to meet its goal and be able to achieve competitive advantage. According to Obiageli et al. (2015), organization success depends on the employee performance. Therefore, it is important for a manager to create a well-grounded approach for managing and coaching the workforce. Furthermore, Obiageli et al. (2015) state that "commercial banks are service industry and their main aim is to satisfy their customer. The service employee renders to the customer and employee performance is interrelated. When employees provide excellent customer service, they are exceeding job expectations. The popularity of an organization's service is based in part on the level of service received by the customer. For service industry the business is based almost solely on their employee's performance. That is why management must look for various ways in improving employee performance". Borman and Motowidlo (1993) revealed two strands of employee behavior that are necessary for organizational effectiveness: task performance and contextual performance. Task performance are behaviors employee exhibits that directly involved in producing goods or service, or activities that provide indirect support for the organization's core technical processes (Borman \& Motowidlo, 1993; Werner, 2000). They further opined that these behaviors directly relate to the formal organization reward system. On the other hand, contextual performance is referred to the individual efforts exerted that are not directly related to their main task functions. Though, these behaviors are not recognized and captured neither in the formal task functions nor job description but are important because they shape the organizational, social, and psychological contexts serving as the critical catalyst for task activities and processes (Werner, 2000). Interpersonal facilitation such as cooperative, considerate, and helpful acts that assist co-workers' performance on one hand, and job dedication which is consistent of self-disciplined, motivated acts such as working hard, taking initiative, and following rules to support organizational objectives are two major facets of contextual performance identified by Jankingthong and Rurkkhum (2012). They further revealed that contextual performance and related elements of performance, such as organizational citizenship behavior (OCB) contribution of (Bateman and Organ, 1983), prosocial organizational behavior, and extra-role performance (Van Dyne et al., 1995), contribute to organizational effectiveness.

\subsection{Goal Attainment}

Goals are specific targeted achievements of an individual or organization. Goals have a pervasive in-

fluence on employee behavior and performance in organizations and management practice (Locke \& Latham, 2002). "Nearly every modern organization has some form of goal setting in operation. Pro- 
grams such as management by objectives (MBO), high-performance work practices (HPWPs), management information systems (MIS), benchmarking, stretch targets, as well as systems thinking and strategic planning, include the development of specific goals" (Fred, 2011). Furthermore, Fred opined that goal setting which aids employee's goal attainment is the underlying explanation for all major theories of work motivation- Be it Vroom's (1994) VIE theory, Maslow's (1970) or Herzberg's (2009) motivation theories, Bandura's (1986) social cognitive theory, or operant-based behaviorism. Managers widely accept goal setting as a means to improve and sustain performance (DuBrin, 2012).

Employees perform at higher levels when asked to meet a specific goal target. Requesting employees to improve, to work harder, or to do their best is not helpful, because that kind of goal does not give them a focused target. Goal specification enables members know what target to attain and allow them to measure their own progress. Research indicates that specific goals help bring about other desirable organizational goals, such as reducing absenteeism, tardiness, and turnover (Locke \& Latham, 2002). Employee becomes more loyal and stay in the organization, meeting the work targets when they identify themselves within a group and contribute to the performance as a group. This suggestion relies on work performed by Locke and Latham goal setting theory. The goal is team performance and the individual feeling part of the group. The focus of Locke was on the goal, but in order to reach the goal one must associate oneself with the group and task.

\section{Methodology}

Descriptive survey research design was adopted for the study. This design is deem appropriate for the current study based on the fact that the population and sample of the study are spread across different locations within South- South, Nigeria. Data was collected from primary and secondary sources of one thousand eight hundred and forty three (1843) staff population of twelve (12) money deposit banks in South- South zone of Nigeria comprising; Rivers, Bayelsa, Edo, Delta and Cross Rivers and Akwa Ibom State. Cochran sample size determination statistical formula for finite population was adopted in determining the sample size of 485 for the study. Thus it is stated:

$$
n=\frac{N \times z_{\alpha / 2}^{2} \times p \times q}{\varepsilon^{2} \times(N-1)+z_{\alpha / 2}^{2} \times p \times q},
$$

where $N$ is the population size, $p=1-q$ represents the yes/no categories, $z_{\alpha / 2}$ is CDF of normal distribution and finally $\varepsilon$ is the error term. Since we have $p=0.5, z_{\alpha / 2}=1.96$ and $N=2526$, the number of sample size is calculated as $n=485$.

Table 1

Population of the Selected Money Deposit Banks within the State capital in South- South, Nigeria

\begin{tabular}{|c|c|c|c|c|c|c|c|}
\hline BANKS & $\begin{array}{l}\text { Rivers } \\
\text { Staff }\end{array}$ & $\begin{array}{c}\text { Bayelsa, } \\
\text { Staff }\end{array}$ & $\begin{array}{l}\text { Edo, } \\
\text { Staff }\end{array}$ & $\begin{array}{c}\text { Delta } \\
\text { Staff }\end{array}$ & $\begin{array}{l}\text { C.Rivers } \\
\text { Staff }\end{array}$ & A. Ibom & Total \\
\hline First Bank Plc & 86 & 76 & 60 & 89 & 54 & 34 & 399 \\
\hline Zenith Bank Plc & 36 & 41 & 21 & 43 & 32 & 33 & 206 \\
\hline Eco Bank & 17 & 71 & 23 & 52 & 29 & 34 & 226 \\
\hline UBA & 23 & 76 & 32 & 53 & 44 & 32 & 260 \\
\hline Access Bank Plc, & 31 & 62 & 24 & 48 & 23 & 31 & 219 \\
\hline Guarantee Trust Bank & 42 & 71 & 18 & 44 & 37 & 32 & 244 \\
\hline Sterling bank & 22 & 36 & 15 & 18 & 21 & 31 & 143 \\
\hline Diamond bank & 48 & 39 & 33 & 23 & 32 & 33 & 208 \\
\hline Fidelity bank Plc & 34 & 33 & 12 & 28 & 27 & 29 & 163 \\
\hline Stanbic IBTC & 28 & 32 & 21 & 32 & 32 & 28 & 173 \\
\hline Skye Bank Plc & 18 & 26 & 17 & 23 & 21 & 31 & 136 \\
\hline FCM & 32 & 22 & 24 & 26 & 23 & 22 & 149 \\
\hline TOTAL & 417 & 585 & 300 & 479 & 375 & 370 & 2526 \\
\hline
\end{tabular}

Source: Personnel Department of the selected Deposit Money Banks 
Content and face validation were used to validate the instrument use and Spearman ranking order correlation coefficient was used to test the reliability of the instrument from the two set of responses by 15 respondents. The formula is as follows,

$$
r=1-\frac{6 \sum_{i=1}^{n} d_{i}^{2}}{n\left(n^{2}-1\right)},
$$

where:

$$
\begin{aligned}
& r=\text { spearman's rank correlation, } \\
& \mathrm{d}=\text { difference between rank of the responses (i.e. } \mathrm{R}_{\mathrm{x}}-\mathrm{R}_{\mathrm{y}} \text { ) } \\
& \mathrm{n}=\text { number of respondents. }
\end{aligned}
$$

\begin{tabular}{|c|c|c|c|c|c|c|}
\hline Respondents & $1^{\text {st }}$ Test & $2^{\text {nd }}$ Test & $\mathrm{R}_{1 s t}$ & $\mathrm{R}_{2 \text { nd }}$ & $\mathrm{d}$ & $\mathrm{d}^{2}$ \\
\hline 1 & 83 & 82 & 5 & 6 & -1 & 1 \\
\hline 2 & 78 & 80 & 11 & 9 & 2 & 4 \\
\hline 3 & 88 & 85 & 3 & 4 & -1 & 1 \\
\hline 4 & 85 & 86 & 4 & 3 & 1 & 1 \\
\hline 5 & 82 & 80 & 7 & 9 & -2 & 4 \\
\hline 6 & 89 & 88 & 1 & 1 & 0 & 0 \\
\hline 7 & 77 & 81 & 14 & 8 & 6 & 36 \\
\hline 8 & 79 & 82 & 10 & 6 & 4 & 16 \\
\hline 9 & 80 & 79 & 9 & 11 & -2 & 4 \\
\hline 10 & 82 & 83 & 7 & 5 & 2 & 4 \\
\hline 11 & 83 & 79 & 5 & 11 & -6 & 36 \\
\hline 12 & 76 & 83 & 15 & 13 & 2 & 4 \\
\hline 13 & 73 & 79 & 18 & 16 & 2 & 4 \\
\hline 14 & 75 & 77 & 16 & 13 & 3 & 9 \\
\hline 15 & 67 & 69 & 21 & 21 & 0 & 0 \\
\hline 16 & 78 & 75 & 11 & 16 & -5 & 25 \\
\hline 17 & 78 & 74 & 11 & 18 & -7 & 49 \\
\hline 18 & 89 & 88 & 1 & 1 & 0 & 0 \\
\hline 19 & 75 & 77 & 16 & 13 & 3 & 9 \\
\hline 20 & 65 & 67 & 22 & 22 & 0 & 0 \\
\hline 21 & 62 & 65 & 23 & 23 & 0 & 0 \\
\hline 22 & 60 & 63 & 25 & 24 & 1 & 1 \\
\hline 23 & 61 & 59 & 24 & 25 & -1 & 1 \\
\hline 24 & 69 & 70 & 20 & 20 & 0 & 0 \\
\hline 25 & 70 & 72 & 19 & 19 & 0 & 0 \\
\hline
\end{tabular}

Table 2

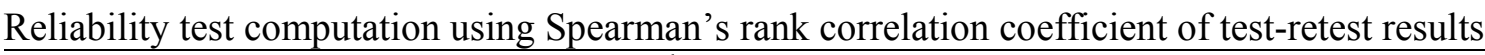

The computed Spearman's Rank Correlation Coefficient ( $r$ ) was 0.92. However, with $r=0.92$, the reliability of the test instrument is very strong, as $r>0.7$.

\section{Results}

\subsection{Data Presentation}

Table 3

Analysis Showing Questionnaire Distribution and Return Percentage

\begin{tabular}{lllllll}
\hline & No. & $\%$ & No. & $\%$ & No. Not & $\%$ Not \\
& Distributed & Distributed & Returned & Returned & Returned & Returned \\
\hline Rivers & 80 & 16 & 78 & 16 & 2 & 0.4 \\
Bayelsa & 112 & 23 & 109 & 22.4 & 3 & 0.6 \\
Edo & 58 & 12 & 58 & 12 & - & - \\
Delta & 92 & 19 & 87 & 18 & 5 & 1.0 \\
Cross River & 72 & 15 & 69 & 14 & 3 & 0.6 \\
Akwa Ibom & 71 & 15 & 71 & 15 & - & - \\
\hline Total & 485 & 100 & 472 & 97.4 & 13 & 2.6 \\
\hline Sour
\end{tabular}


As shown in Table 3 a total number of four hundred and eighty five (485) copies of questionnaire were administered by the researcher with five trained research assistant on the staff of the selected deposit money banks in South-South, Nigeria. Out of the 485 copies of questionnaire sent out 472 were returned, giving a response rate of $97.4 \%$; 13 out of 485 copies of questionnaire administered were not returned, thus, giving a non-response rate of $2.6 \%$.

Table 4

Sex Distribution of Respondents

\begin{tabular}{lll}
\hline & & Respondent Category \\
\hline Sex & Male & 223 \\
& Female & 249 \\
\hline Total & & 472 \\
\hline Source: Field Survey, 2018 &
\end{tabular}

The gender of the respondents was studied in order to ascertain the pattern of distribution of the respondents according to their gender. From the analysis of Table 4, it is evident that female participants out-numbered their male counterparts. As many as $249(53 \%)$ who participated in the study were females while 223 (47\%) were male.

Table 5

Age Distribution of Respondents

\begin{tabular}{lcc}
\hline Age Range & Frequency & Percentage \\
\hline $25-30$ & 271 & 57 \\
$31-40$ & 154 & 33 \\
$41-60$ & 47 & 10 \\
\hline Total & 472 & 100 \\
\hline
\end{tabular}

Source: Field Survey, 2018

Table 5 indicates that $271(57 \%)$ of the respondents are within $25-30$ years, $154(33 \%)$ are within 31 40 years, $47(10 \%)$ are within $41-60$ years.

Table 6

Educational Qualifications of Participants

\begin{tabular}{lcc}
\hline Qualifications & Freg. & Percent $(\%)$ \\
\hline Diploma & 82 & 17 \\
B.Sc/HND & 378 & 80 \\
Masters & 12 & 3 \\
\hline Total & 472 & 100
\end{tabular}

The educational qualification of the respondents was studied in order to find their literacy level. The result of the analysis as shown in Table 6 reveals that $82(17 \%)$ respondents had Diploma, $378(80 \%)$ of the respondents were holders of B.Sc/HND, and $12(3 \%)$ of the participants were holders of Masters degree. The result shows that the respondents have reasonable level of education. Thus, this made the responses by them reliable.

Table 7

Marital Status of the Respondents

\begin{tabular}{lcc}
\hline Marital Status & Freq. & Percent (\%) \\
\hline Single & 296 & 63 \\
Married & 176 & 37 \\
\hline Total & 472 & 100
\end{tabular}

Source: Field Survey, 2018

Table 7 reveals $296(63 \%)$ respondents were single while $176(37 \%)$ were single. 


\subsection{Test of Hypotheses}

Ha1: Alternate work arrangement such as telecommuting, flexi time, job sharing and compress work weeks has a positive relationship with Goal attainment in deposit money banks, South-South, Nigeria.

\section{Table 8}

Descriptive Statistics of alternative work arrangement (telecommuting, flexi time, job sharing and compress work) and Goal attainment

\begin{tabular}{lccc}
\hline Variables & $\mathrm{N}$ & Mean & Std. Deviation \\
\hline Goal attainment & 472 & 3.65 & 2.07 \\
Telecommuting & 472 & 4.08 & 2.18 \\
flexi time & 472 & 3.75 & 2.98 \\
Job sharing & 472 & 3.15 & 2.85 \\
compress work weeks & 472 & 3.29 & 2.95 \\
\hline
\end{tabular}

Source: Author's Computation, 2018

Table 8 shows the descriptive statistics of mean $(\mathrm{m})$, standard deviation (std. deviation) and number of cases (respondents) $(\mathrm{N})$ to determine the nature of relationship between alternative work arrangement (telecommuting, flexi time, job sharing and Compress work weeks) and Goal attainment. Goal attainment has mean of (3.65), std. deviation (2.07) and number of respondents (472), telecommuting had mean of (4.08), std. deviation (2.18) and number of respondents (472), flexi time had mean of (3.75), std. deviation (2.98) and number of respondents (472) and job sharing has mean of (3.15), std. deviation (2.85) and number of respondents (472) and compress work weeks has mean of (3.19), std. deviation ( 2.95) and number of respondents (472). By careful observation of the standard deviation values, there is not much difference in terms of the standard deviation scores. This implies that there is about the same variability of data points amongst the dependent and independent variables.

\section{Table 9}

Multiple Correlation Matrix on the Relationship between alternative work arrangement (telecommuting, flexi time, job sharing and compress work weeks ) and goal attainment

\begin{tabular}{|c|c|c|c|c|c|c|}
\hline & & Goal attainment & Telecommuting & Flexi Time & Job sharing & Compress work \\
\hline \multirow[t]{3}{*}{ Goal attainment } & Pearson Correlation & 1 & $.939 * *$ & $.895 * *$ & $.628 * *$ & $.534 * *$ \\
\hline & Sig. (2-tailed) & & .000 & .001 & .000 & .000 \\
\hline & $\mathrm{N}$ & 472 & 472 & 472 & 472 & 992 \\
\hline \multirow[t]{3}{*}{ Telecommuting } & Pearson Correlation & $.939^{* *}$ & 1 & $.689 * *$ & $.708 * *$ & $.534 * *$ \\
\hline & Sig. (2-tailed) & & & .000 & .000 & .000 \\
\hline & $\mathrm{N}$ & 472 & 472 & 472 & 472 & 472 \\
\hline \multirow[t]{4}{*}{ Flexi Time } & & $.895 * *$ & $.689 * *$ & & & \\
\hline & Pearson Correlation & .001 & .000 & 1 & $.743 * *$ & $.708^{* *}$ \\
\hline & Sig. (2-tailed) & & & & .000 & .000 \\
\hline & $\mathrm{N}$ & 472 & 472 & 472 & 472 & 472 \\
\hline \multirow[t]{3}{*}{ Job sharing } & Pearson Correlation & $.628 * *$ & $.708^{* *}$ & & 1 & $.689 * *$ \\
\hline & Sig. (2-tailed) & .000 & .000 & .000 & & .000 \\
\hline & $\mathrm{N}$ & 472 & 472 & 472 & 472 & 472 \\
\hline \multirow[t]{3}{*}{ Compress work } & Pearson Correlation & $.534 * *$ & $.689 * *$ & . & $.895 * *$ & 1 \\
\hline & Sig. (2-tailed) & .000 & .000 & .000 & .001 & \\
\hline & $\mathrm{N}$ & 472 & 472 & 472 & 472 & 472 \\
\hline
\end{tabular}

Table 9 is the Pearson correlation matrix of Goal attainment, telecommuting, flexi time, job sharing and compress work showing the correlation coefficients, significant values and the number of cases. The result in the multiple correlation matrix shows that there was a relationship between telecommuting and Goal attainment $(\mathrm{r}=.84)$; relationship between flexi time, and Goal attainment $(\mathrm{r}=.89)$; relationship between job sharing and Goal attainment $(\mathrm{r}=.67)$; relationship between compress work weeks and Goal attainment $(\mathrm{r}=.59)$ The computed correlation coefficients of the relationship between alternative work arrangement (telecommuting, flexi time, job sharing and compress work) and Goal attainment ( $\mathrm{r}$ $=.84 ; \mathrm{r}=89 ; \mathrm{r}=.67 ; \mathrm{r}=.59$ ) respectively are greater than the table value of $\mathrm{r}=.195$ with 470 degrees of freedom $(\mathrm{df} .=\mathrm{n}-2)$ at alpha level for a two-tailed test $(\mathrm{r}=.84, \mathrm{p}<0.05 ; \mathrm{r}=.89 \mathrm{p}<0.05 ; \mathrm{r}=.67 \mathrm{p}$ 
$<0.05 ; \mathrm{r}=.59 \mathrm{p}<0.05$ ). Since the computed $\mathrm{r}=84, \mathrm{r}=89, \mathrm{r}=67, \mathrm{r}=59$ are greater than the table value of .195 we reject the null hypothesis and concluded that telecommuting, flexi time, job sharing and compress work week have a positive relationship with Goal attainment in deposit money banks, South-South, Nigeria.

\subsection{Test of Hypothesis Two}

$\mathrm{Ha}_{2}$ Managerial supports affect goal attainment in deposit money banks, South-South, Nigeria.

Model 2: $G A=\beta_{0}+\beta_{3} M S+\mu_{1}$

In testing this hypothesis, data were tested using Simple Linear Regression. The results of the Regression on GA and MS are shown in Table 10a, Table 10b and Table 10c.

Table 10a

Model Summary

\begin{tabular}{llllll}
\hline Model & $\mathrm{R}$ & R Square & Adjusted R Square & Std. Error of the Estimate Durbin-Watson \\
\hline 1 & $.931^{\mathrm{a}}$ & .625 & .649 & .68430 & 1.694 \\
\hline a. & Predictors: (constant), Managerial supports & & & \\
b. & Dependent Variable: Goal attainment & &
\end{tabular}

\section{Table 10b}

The results of ANOVA ${ }^{\mathrm{b}}$

\begin{tabular}{llllll}
\hline & Sum of Squares & Df & Mean Square & F & Sig. \\
\hline $1 \quad$ Regression & 162.012 & 1 & 121.421 & 5.45 & $.0001^{\mathrm{a}}$ \\
Residual & 97.147 & 34 & 22.278 & & \\
\hline Total & 259.159 & 35 & & & \\
\hline
\end{tabular}

a. Predicator: (Constant), Managerial supports

b. Dependent Variable: Goal attainment

Table Table $10 \mathrm{c}$

The results of regression model

\begin{tabular}{|c|c|c|c|c|c|c|}
\hline \multirow{2}{*}{\multicolumn{2}{|c|}{ Model }} & \multicolumn{2}{|c|}{$\begin{array}{c}\text { Unstandardized } \\
\text { Coefficients }\end{array}$} & \multirow{2}{*}{$\begin{array}{c}\text { Standardized } \\
\text { Coefficients }\end{array}$} & & \multirow{2}{*}{$\frac{\text { Sig. }}{\mathrm{P}}$} \\
\hline & & $\mathrm{B}$ & Std. Error & & $\mathrm{T}$ & \\
\hline 1 & (Constant) & 29.31 & 3.89 & & 7.53 & .001 \\
\hline & Managerial supports & 15.98 & 2.312 & .931 & 6.91 & .001 \\
\hline
\end{tabular}

Dependent Variable: Goal attainment

Table $10 \mathrm{a}$ and $10 \mathrm{~b}$ show that the analysis of variance of the fitted regression equation is significant with $F$ value of 5.45; this is an indication that the variation explained by the model is not due to chance. Since the p-value $(0.001)$ is less than 0.05 , it shows a statistically significant positive effect between the variables at 95 percent confidence level. Therefore, the null hypothesis of no significant effect is rejected. Thus, managerial supports has a significant positive effect on goal attainment in deposit money banks, South-South, Nigeria. The $\mathrm{R}^{2}$ statistic indicates that the model as fitted explains 89.5 percent of the total variability in goal attainment. In other words, 89.5 percent of the total variability in goal attainment can be explained by managerial supports. The value of $\mathrm{R}^{2}=0.625$ shows that managerial supports is a good predictor of goal attainment. The standardized coefficients (Beta) value in Table $4.10 \mathrm{c}$ reveals that the independent variable is statistically significant at 0.05 significant level. The null 
hypothesis is therefore rejected and the alternative hypothesis accepted. Thus we conclude that managerial supports has a significant positive effect on goal attainment in deposit money banks, SouthSouth, Nigeria.

\section{Conclusion and recommendation}

The study examined the effect of work-life balance on the performance of money deposit banks in

South-South, Nigeria. Hence, arising from the results and discussion of participants' responses, the study concluded that alternative work arrangement such as compress work weeks, telecommuting, flexi time, and job sharing and managerial supports serves as a motivator to employees and enhances their efficiency in attaining set goals. Finally, the study concluded that non adherence by the management of money deposit banks in South- south, Nigeria to work-life balance initiatives was the major challenge to employees' performance, retention, and the overall actualization of set goals among deposit money bank in South- south, Nigeria.

Based on the findings and the conclusion of this study, we made the following recommendations which will be relevant, not only to the deposit money banks in South- south, Nigeria but also to the entire banking industry, the policy makers and the practitioners of other sectors in Nigeria.

i. The management of deposit money banks in South- south, Nigeria should know that one-sided "systems" approach to work-life issues without considering the "individual" side of the organization is detrimental to the growth of the organization because work-life balance is more an individual issue that affects the organization than it is an organizational issue that affects the individual. The management should judiciously adopt and implement alternative work arrangement in order to offer a family-friendly atmosphere to attract and retain qualified employees for increase productivity.

ii. The management should know that unbalanced work-family life caused by increased work demands leads to higher levels of stress and stress caused by higher demands from work results in family-work conflicts which impacts negatively not only on the wellbeing of workers but also on their families and the organizational goal.

iii. The captains of deposit money bank must realize that job satisfaction is a key tool in employee retention and goal attainment. They should consciously and intelligently design and fashion out as a matter of employee support leave system that creates a change of environment and impacts positively on employees' psychosocial well-being in order to keep the morale of employees high.

\section{Acknowledgement}

The authors would like to thank the anonymous referees for constructive comments on earlier version of this paper.

\section{References}

Allen, T. D. (2001). Family-supportive work environments: The role of organizational perceptions. Journal of vocational behavior, 58(3), 414-435.

Amjad Ali, C., Kundi, G. M., Qureshi, Q. A., \& Akhtar, R. (2014). Relationship between work-life balance \& organizational Commitment. Research on Humanities and Social Sciences, 4(5), 1-7.

Anderson, S. E., Coffey, B. S., \& Byerly, R. T. (2002). Formal organizational initiatives and informal workplace practices: Links to work-family conflict and job-related outcomes. Journal of management, 28(6), 787-810.

Bateman, T. S., \& Organ, D. W. (1983). Job satisfaction and the good soldier: The relationship between affect and employee "citizenship". Academy of management Journal, 26(4), 587-595. 
Benardin, H. I., \& Rusell, J. E. (1998) Human resource management: an experimental approach. 2nd ed. Irwin: McGraw- Hill.

Borman, W. C,. \& Motowidlo, S. J. (1993) Expanding the criterion domain to include elements of contextual performance. Personnel Selection in Organizations. San Francisco: Jossey-Bass.

Campbell, I. (1993). Labour market flexibility in Australia: Enhancing management prerogative?. Labour \& Industry: a Journal of the Social and Economic Relations of Work, 5(3), 1-32.

Clark, S. C. (2001). Work cultures and work/family balance. Journal of Vocational Behavior, 58(3), 348-365.

DuBrin, A. J. (2012). Essentials of management. Mason, OH: Cengage South-Western.

Eby, L. T., Casper, W. J., Lockwood, A., Bordeaux, C., \& Brinley, A. (2005). Work and family research in IO/OB: Content analysis and review of the literature (1980-2002). Journal of vocational behavior, 66(1), 124-197.

Fred, L. C. (2011). Goal-Setting Theory of Motivation. International Journal of Management, Business, and Administration, 15(1).

Frese, M., Brantjes, A., \& Hoorn, R. (2002). Psychological success factors of small scale businesses in Namibia: The roles of strategy process, entrepreneurial orientation and the environment. Journal of developmental Entrepreneurship, 7(3), 259-282.

Glass, J., \& Fujimoto, T. (1995). Employer characteristics and the provision of family responsive policies. Work and Occupations, 22(4), 380-411.

Greenhaus, J. H., \& Beutell, N. J. (1985). Sources of conflict between work and family roles. Academy of management review, 10(1), 76-88.

Hill, E. J., Hawkins, A. J., Ferris, M., \& Weitzman, M. (2001). Finding an extra day a week: The positive influence of perceived job flexibility on work and family life balance. Family relations, 50(1), 49-58.

Ilgen, D. R., \& Schneider, J. (1991). Performance measurement: A multi-discipline view. International review of industrial and organizational psychology, 6, 71-108.

Jankingthong, K., \& Rurkkhum, S. (2012). Factors affecting job performance: a review of literature. Humanities, Arts and Social Sciences Studies (FORMER NAME SILPAKORN UNIVERSITY JOURNAL OF SOCIAL SCIENCES, HUMANITIES, AND ARTS), 12(2), 115-128.

Konrad, A. M., \& Mangel, R. (2000). The impact of work-life programs on firm productivity. Strategic management journal, 21(12), 1225-1237.

Locke, E. A., \& Latham, G. P. (2002). Building a practically useful theory of goal setting and task motivation: A 35-year odyssey. American psychologist, 57(9), 705.

Lockwood, N.R. (2003). Work/Life Balance: Challenges and Solutions, Society for Human Resource Management: Research Quarterly, 2, 1-10.

Marks, S. R., \& MacDermid, S. M. (1996). Multiple roles and the self: A theory of role balance. Journal of Marriage and the Family, 58(2), 417-432.

Naithani, P. (2010). Overview of Work-life balance discourse and its relevance incurrent economic scenario. Asian Social Science, 6(6), 148-155.

Obiageli, O. L., Uzochukwu, O. C., \& Ngozi, C. D. (2015). Work life balance and employee performance in selected commercial banks in Lagos State. European Journal of Research and Reflection in Management Sciences, 3(4).

Oludayo, O. O., Gberevbie, D. E., Popoola, D., \& Omonijo, D. O. (2015). A study of multiple worklife balance initiatives in banking industry in Nigeria. A Study of Multiple Work-life Balance Initiatives in Banking Industry in Nigeria, (133), 108-125.

Rhoades, L., \& Eisenberger, R. (2002). Perceived organizational support: a review of the literature. Journal of applied psychology, 87(4), 698.

Shobitha, P., \& Sudarsan, N. (2014). Work life balance: A conceptual review. International Journal of Advances in Management and Economics, 3(2), 1-17.

Smith, K. E., Johnson, R. W., \& Muller, L. A. (2004). Deferring Income in Employer-Sponsored Retirement Plans: The Dynamics of Participant Contributions. National Tax Journal, 57(3), 639-670. 
Sturges, J., \& Guest, D. (2004). Working to live or living to work? Work/life balance early in the career. Human Resource Management Journal, 14(4), 5-20.

Tayfun, A., \& Çatir, Ö. G. O. (2014). An empirical study into the relationship between work/life balance and organizational commitment. ISGUC The Journal of Industrial Relations and Human Resources, 16(1), 20-37.

Valk, R., \& Srinivasan, V. (2011). Work-family balance of Indian women software professionals: A qualitative study. IIMB Management Review, 23(1), 39-50.

Van Dyne, L., Cummings, L. L., \& Parks, J. M. (1995) Extra-role behaviors: In pursuit of construct and definitional clarity (a bridge over muddied waters). In Research in Organizational Behavior(L. L. Cummings \& B. M. Staw, eds), pp. 215-285. Greenwich, CT: JAI Press.

Warren, J. A., \& Johnson, P. J. (1995). The impact of workplace support on work-family role strain. Family relations, 44(2), 163-169.

Warren, T. (2004). Working part-time: achieving a successful 'work-life'balance? 1. The British journal of sociology, 55(1), 99-122.

Werner, J. M. (2000). Implications of OCB and contextual performance for human resource management. Human Resource Management Review, 10(1), 245-261.

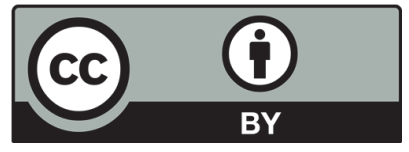

(C) 2019 by the authors; licensee Growing Science, Canada. This is an open access article distributed under the terms and conditions of the Creative Commons Attribution (CC-BY) license (http://creativecommons.org/licenses/by/4.0/). 